УДК 159.938

DOI https:// doi.org/10.32837/yuv.v0i1.1566

\author{
О. Никифорова, \\ кандидат біологічних наук, доцент, \\ доцент кафедри тактико-спеціальної підготовки \\ Дніпропетровського державного університету внутрішніх справ \\ О. Бойко, \\ викладач кафедри тактико-спеціальної підготовки \\ Дніпропетровського державного університету внутрішніх справ
}

\title{
ОПТИМІЗАЦІЯ ПРОФЕСІЙНО ВАЖЛИВИХ ЯКОСТЕЙ У МАЙБУТНІХ ПРАЦІВНИКІВ ПАТРУЛЬНОЇ ПОЛІЦІї
}

Діяльність поліцейських постійно супроводжується високим рівнем відповідальності, великим психоемоційним навантаженням, особливо при безпосередній взаємодії зі злочинними угрупованнями, участі в розгоні масових заворушень та ін. У співробітників $є$ і проблеми соціально-побутового характеру, що негативно позначаються не тільки на їхньому психічному стані, a й на морально-психологічному кліматі всередині сім'ї, коли поліцейський не має можливості приділяти достатньо уваги родині через ненормований робочий графік.

Довге перебування під впливом негативного емоційного фону (стану провини, тривоги, незадоволеності, жорстокості, агресивності, невпевненості тощо), невміння самостійно зменшити ступінь переживання через несприятливі фактори небезпечне, адже руйнівно вПливає не тільки на психічне самопочуття, а й на соматичний стан організму загалом [1].

У цих скрутних ситуаціях змінюється психічний стан поліцейських, що призводить до поступових психофізичних змін особистості, погіршення самопочуття, неможливості нормально працювати, а в тяжких випадках - навіть до втрати професіоналізму і звільнення з лав правоохоронних органів.

Досвід спостереження за поведінкою працівників поліції показав, що невміння регулювати свій внутріш- ній психічний стан може негативно позначатися на взаєминах із близькими і друзями, на якості виконуваної роботи $[2 ; 3]$.

Факторів, які детермінують процес адаптації поліцейських до підвищених вимог професії, дуже багато. Насамперед це професіоналізм, зумовлений знаннями, вміннями, навичками та, звичайно, досвідом.

Несприятливі психічні стани (напруг, тривога, фрустрація, афект, стрес) розглядаються у психології як емоційно-вольові реакції, що можуть починатися із провісників і розвиватися непомітно (негативізм, бурчання, різні ступені вираження жорстокості у відносинах із людьми, агресивність). Ступінь їх прояву у поліцейських залежить від інтенсивності та частоти стресових чинників професійного, навчального та побутового середовища. Часто психоемоційні стани, наприклад, агресія, жорстокість, дратівливість, негативізм, можуть бути різними ознаками прояви невігластва, нестачі знань, виховання, які можна усунути у процесі навчання та психокорекції. Ці реакції найчастіше формуються під час адаптації до підвищених вимог середовища i в періоди накопичення втоми. Відсутність профілактики таких станів (як демонструє практика) може спричинити незворотні наслідки як для окремо взятого працівника поліції, так і для всієї правоохоронної системи. Багато випадків, коли 


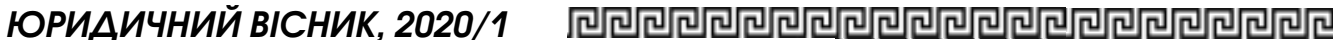

накопичення несприятливих психічних переживань призвели до негативних результатів, що відбилися як на самому працівникові, так і на репутації правоохоронної системі загалом. Тому відповідно до Порядку організаціі системи психологічного забезпечення поліцейських, працівників Національної поліції України та курсантів (слухачів) закладів вищої освіти зі специфічними умовами навчання, котрі здійснюють підготовку поліцейських (Наказ МВС України від 06 лютого 2019 р. № 88) повинні проводитися заходи щодо покращення психологічного статусу в підрозділах. Але різні види негативного емоційного реагування виникають особливо гостро, коли з метою зниження інтенсивності напруги вживаються спиртні напої або інші допінги. У зв'язку з цим психопрофілактика негативних психічних станів у працівників особливо актуальна. 3 огляду на викладене вважаємо, що несприятливі психічні стани можна скорегувати тренінгами, які сформують умови для усунення чинника нестачі знань, умінь, навичок і досвіду, що перешкоджають адаптації співробітників до вимог професії на стадії навчання поліцейських на різних етапах підготовки.

Мета роботи - проаналізувати вплив певних знань, умінь, навичок i процесу навчання загалом на динаміку розвитку передвісників несприятливих психічних станів слухачів - майбутніх працівників патрульної поліції.

У наших дослідженнях ми вивчали структуру властивостей особистості, яка характеризує формування симптомів, що трактували помилково не як процес адаптації до вимог професії, а як «синдром емоційного вигорання», торкаючись зв'язку професійних і особистісних якостей працівників поліції.

Проведені раніше дослідження, орі$є$ єтовані на виявлення професійно важливих якостей (далі - ПВЯ), показали, що необхідно визначити профіль особистості, стрижневі особистісні якості, оскільки на їхній основі надалі розвивається професійний, життєвий досвід і комунікативна компетентність [6-8]. Для працівників поліціі, які часто задіяні в тих сферах професійної діяльності, де характер праці висуває особливі вимоги і $є$ ризики формування несприятливих психічних станів, важливе проведення тестової психодіагностики. У цьому аспекті певний інтерес становлять дослідження наших колег. 3 урахуванням названих позицій більш логічним і обгрунтованим, на наш погляд, буде (в теорії та практиці) формування процесу професійного становлення особистості шляхом накопичення знань, умінь і навичок, які нині трактуються як компетентність. Дослідження проводилися у групах (спостереження і тестування) за стандартною методикою дослідження негативних комунікативних установок і психологічного захисту у спілкуванні В.В. Бойко [1; 4].

Експериментальні спостереження у цьому ракурсі зі слухачами дозволили певною мірою систематизувати психологічні рівні формування цих понять.

Перший рівень формування поняття «професія» і становлення професіонала в навчальних установах системи MBC становлять знання. Вони представляють сукупність інформації, отриманої в теоретичній або емпіричної площині даних. В аспекті діяльності поліцейських вони можуть бути розділені на кілька груп, на яких зводиться фундамент належності до певної професії. До першої групи відносять знання загальноорганізаційного характеру, якими тією чи іншою мірою повинні володіти практично всі працівники поліції. За нашими оцінками, це найчастіше знання системи правоохоронних органів, а також ряду основних законів i нормативних правових документів, що регулюють питання функціонування Національної поліції в різних напрямах діяльності. Другу групу становлять загальнопрофесійні знання, необхідні для виконання профільних завдань. Третя група складається 3 вузьких (або вузькопрофільних) професійно-прикладних знань, необхідних працівникові для ефективного виконання 
завдань в усіх напрямах професійної діяльності (слідство, дізнання, карний розшук, криміналістика та ін.) [1;8].

Другий рівень формування поняття «професія» у процесі професійного становлення в навчальних установах системи MBC становить поняття «вміння» - зв'язок когнітивних розумових процесів із фізичними можливостями майбутнього поліцейського, тобто коли його знання, трансформовані у практичну площину, успішно застосовуються для отримання бажаного результату, при проходженні практики курсантами у профільних підрозділах Національної поліції. Цей рівень практично завжди забезпечує отримання результатів, відповідних необхідним вимогам, але вміння не завжди трансформуються в навички. Наприклад, вміння знешкодити озброєного злочинця (тобто знання основних технік і правил побудови боротьби, доповнене практикою тренувань) може спочатку викликати у людини тривогу, хвилювання, супроводжуватися невдачами, а в процесі повторення приводитиме до успіху i формування певних навичок. Третій, вищий рівень формування навички характеризується низкою елементів, яких немає в уміннях: поява злагодженого зв'язку між рівнями викликається емоційним, фізичним і розумовим напруженням; більш скороченим часовим інтервалом між отриманням мозком сигналу про необхідність дії і здійсненням іi; гарантовано гарною якістю продукту внаслідок застосування досвіду. Знання, накладені на практику ї застосування поліцейським, спочатку формують у нього уміння, які в разі тривалого успішного вирішення певних завдань і виконання службових операцій сприяють формуванню досвіду [2; 7]. У курсантів навички формуються тільки за певними напрямами (володіння зброєю, самооборони, надання домедичної допомоги та ін.). Але коли вони почнуть самостійну діяльність, вміння і навички, відпрацьовані у процесі навчання, посприяють через певний час появі досвіду.
Досвід - це головний фактор переходу умінь і навичок у ранг професіоналізму. При зниженні об'ємних характеристик або при виникненні тимчасового вакууму невикористання навички можуть зворотно трансформуватися в уміння. Отже, досвід - це продукт безперервного вдосконалення. Знання, вміння і навички при їх застосуванні у сфері діяльності завжди проходять крізь призму особистісних якостей і цінностей кожного працівника поліції. У поліцейських ця форма вважається інстинктивною для психологічного захисту і посилюється в щоденній і одноманітно важкій роботі. Водночас працівники поліціі часто $€$ мішенню для критики i звинувачень із боку громадян, засобів масової інформаціï, системи правосуддя, прокуратури, власної адміністрації. За таких умов у багатьох поліцейських властиві їм сміливість, активність, рішучість змінюються інертністю і почуттям провини як реакцією на професійний стрес [8; 10]. Це веде до появи суперечливих тенденцій, породжує внутрішній конфлікт. Крім стресів, пов'язаних зі специфікою роботи та соціальним тиском, негативний вплив на працівника поліціï призводить до погіршення домашніх і службових відносин, що посилює сукупний ефект накопичення втоми, який зношує захисні механізми організму, роблячи його більш уразливим в екстремальних ситуаціях. Уміння поєднувати здатності керувати і підкорятися вимагає від людини не тільки певного запасу знань та ерудиції, але й наявності розумової гнучкості, досвіду [8; 12]. Для вивчення розвиваючого i коригуючого впливу навчання (навчального процесу) на ПВЯ ми спостерігали 4 групи курсантів Академії патрульної поліції м. Київ - майбутніх поліцейських, на яких ще не вплинули чинники професійної діяльності, що впливають на психічний стан.

Досліджувані показники аналізували до навчання формування комунікативної компетентності та конструктивної поведінки при спілкуванні 
в соціумі (тренінги) і після проходження курсу. Нижче ми представляємо дані досліджень груп (спостереження i тестування) за методикою комунікативної установки і психологічного захисту у спілкуванні В.В. Бойко [1; 4]. Передвісники несприятливих психічних станів і професійної психічної дезадаптації (перенапруження психіки у зв'язку зі складною трудовою діяльністю чи навчанням) часто проявляються у вигляді завуальованої чи відкритої жорстокості, агресії, «психологічного дискомфорту - бурчання», в побуті це називається нервозністю. Їх можна виявити тестовими методами до того, як це виявиться іншими способами, навіть раніше, ніж це дійде до свідомості оточуючих або самої людини. Тому методи психодіагностики (тобто діагностики психічних властивостей i стану людини) є надійним і тонким інструментом попередження розвитку нервового зриву, алкоголізації, агресії щодо себе й оточуючих.

На рис. 1 і 2 представлений аналіз результатів дослідження на підсумко- вому етапі навчання слухачів. Розподіл середніх результатів попереднього і підсумкового тестування показало зниження прояву негативних комунікативних установок у навчальній групі. Для визначення впливу навчального процесу, що включає тренінг зі спілкування, ми використовували $t$-критерій Стьюдента для залежних вибірок.

Порівняльний аналіз результатів дослідження після закінчення навчального курсу (рис. 1) показує, що у слухачів значно знизився рівень прояви завуальованої ( $<<0,01)$ та відкритої жорстокості (p <0,05). 3'явилося вміння пом'якшити відкритість і різкість у судженнях щодо оточуючих і знаходити способи усунення негативної оцінки, зробленої раніше. На рівні статистичної значущості виявлено зниження проявів негативізму ( $p<0,05)$, що демонструє формування у слухачів вміння розумно переоцінювати ставлення до людей і взаємодіяти у спілкуванні. Рівень бурчання у спілкуванні також статистично значимо знизився ( $p<0,01)$, що свідчить про зникнення

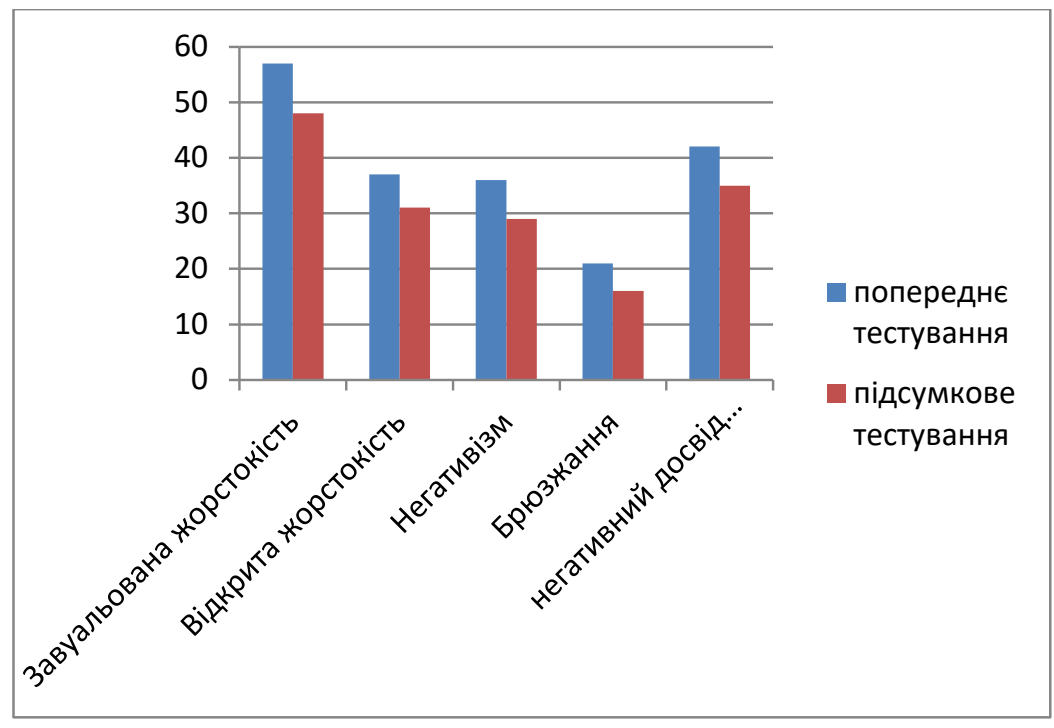

Рис. 1. Порівняльний аналіз результатів дослідження негативних комунікативних установок за методикою В.В. Бойко між попереднім і підсумковим тестуванням після закінчення курсу навчання (бали) 
схильності робити необгрунтовані узагальнення негативних фактів у соціумі. Негативний досвід спілкування знизився ( $p<0,05)$, що говорить про переоцінку та перегляд певних ситуацій у минулому, в яких слухачі переживали конфлікт у навчальній групі та не могли розібратися, хто правий. Рівень прояву психологічного захисту у спілкуванні виявлявся методикою діагностики домінуючої стратегії психологічного захисту у спілкуванні В.В. Бойко (рис. 2). На попередньому тестуванні домінування миролюбності спостерігалося тільки у 18,2\%, тоді як на підсумковому етапі тестування - у 41,6\%.

Для уникнення характерне нульове прагнення до кооперації, відсутність тенденції до досягнення власних цілей. Ми розглядали уникнення як пасивну форму захисту у спілкуванні, воно спостерігалося у $38,2 \%$ курсантів від усієї вибірки до навчання, на підсумковому тестуванні -- тільки у 17\%. Це свідчить про ефективність навчального процесу, який включав навчання конструктивних форм і прийомів асертивності у спілкуванні з партнером. Зниження агресивності щодо партнера теж відображено на рис. 2. Сталося замі- щення домінуючих форм агресивного захисту у спілкуванні миролюбними. Ці результати говорять про формування таких форм поведінки у спілкуванні курсантів, які не призводять до конфліктів і агресії, що дуже важливо виявляти в осіб, яким видається вогнепальна зброя.

Статистичний аналіз показав підвищення рівня миролюбності $(\mathrm{p}<0,05)$ на $29,71 \%$ відносно попереднього тестування і зниження рівня агресивності у спілкуванні (p<0,01) на 28,59\%. Процес навчання (одержання знань, умінь, навичок), будучи основою формування професійно важливих якостей, сприяє зниженню рівня такого несприятливого психічного стану, як агресивність, особливо при навчанні безконфліктним формам подолання бар'єрів спілкування. Дані, отримані при тестуванні до і після навчання, дозволяють говорити про трансформацію несприятливих психічних реакцій у розумні, урівноважені процеси, які викликають накопичення руйнівних, деструктивних наслідків у поведінці майбутніх поліцейських. Прогностичні оцінки, отримані за допомогою статистичного аналізу, показали, що рівень негативізму,

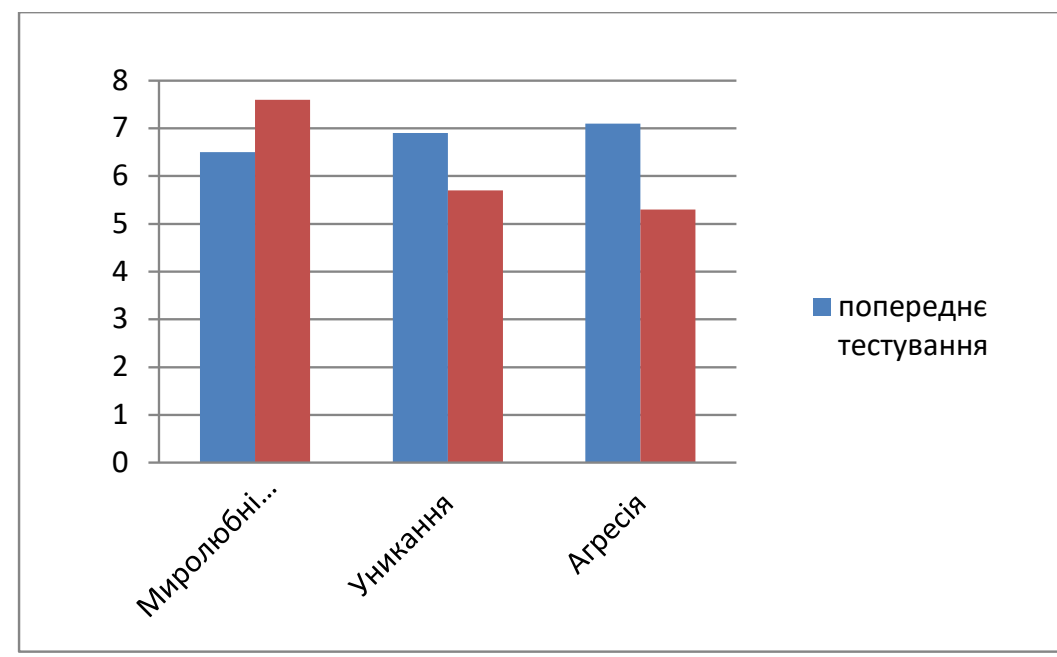

Рис. 2. Порівняльний аналіз результатів дослідження захистів попереднього і підсумкового тестування за методикою В.В. Бойко 


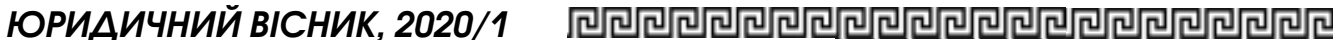

агресії (як характеристики несприятливих психічних провісників і комунікативного бар'єру) знижується за умови підвищення рівня знань, комунікативних здібностей та умінь формувати безконфліктні ситуації.

Несприятливі психічні провісники стану слухачів показали, що зниження психофізичних можливостей пов'язане з порушенням процесів психічної врівноваженості й адаптивності. Після навчання і набуття навичок спілкування намітилася тенденція до зниження відкритого i прихованого жорстокого поводження 3 оточуючими, емоцій негативізму i бурчання, негативного досвіду спілкування і придбання вміння реагувати обдумано в разі агресивного впливу (див. рис. 1, 2).

Результати діагностики домінуючої стратегї психологічного захисту у спілкуванні (див. рис. 2) показали наростання миролюбності, співпраці, компромісу, а загалом - параметрів стійкості до конфліктів, гнучкості у спілкуванні. Виявлено й інші поліпшення у сфері когнітивної й емоційно-вольової сфери.

Проведені дослідження показали, що у процесі навчання нівелюються несприятливі психічні якості особистості, пов'язані з браком знань і, можливо, дефектами виховання, що усуває умови виникнення і розвитку несприятливих психічних станів, зумовлених адаптацією до вимог навчального процесу. Штатним психологам необхідно враховувати, що у багатьох курсантів під час вступу на службу є основа необхідних для професії якостей [6; 12]. У процесі діяльності (у зв'язку з підвищеними вимогами та негативними аспектами середовища), з одного боку, у них накопичується досвід, 3 іншого - відбувається нівелювання необхідних психологічних професійно важливих якостей. Ймовірно, цей феномен пов'язаний із необхідністю у багатьох поліцейських постійної конспірації, із тривалим контактом із негативними явищами соціуму, 3 екстремальними факторами оперативної обстановки, з негативним сприйняттям їх діяльності 3 боку громадян і відсутністю своєчасної кваліфікованої психологічної допомоги [8; 11]. Також, можливо, це пов'язано 3 певними стереотипами в поведінці людини за некомфортних умов. Мається на увазі відсутність бажання спілкуватися із психологами, а іноді - навіть страх осуду перед своїми колегами. Тому проведення подібних навчальних тренінгів - вельми необхідна опція психологічного супроводу слухачів і курсантів в освітніх закладах системи МBC. 3 огляду на викладене вважаємо, що несприятливі психічні стани можна скорегувати тренінгами, які сформують умови для усунення чинника нестачі знань, умінь, навичок і досвіду, які перешкоджають адаптації співробітників до вимог професії, що формується на стадії навчання поліцейських на різних етапах підготовки.

У статті аналізується структура професійо важливих якостей, їх зв'язок із несприятливими психічними станами. Психологічна специиріка пов'язана також із дією таких екстремальних чинників, як небезпека $i$ надзвичайний динамізм розвитку подіü; дефічит часу та інформації; невизначеність можливих варіантів зміни обстановки; необхідність негайного вирішення завдань, шо вимагають нестандартного, творчого підходу; висока відповідальність за наслідки прийнятих рішень. Такі конфліктогенні ситуації чинять значний психологічний вплив на усіх, у т. ч. на працівників правоохоронних органів,. Вони створюють труднощі у вирішенні професійних завдань, позначаються на успішності дій, вимагають від персоналу психологічної стійкості, особливої підготовки, особливого уміння діяти за таких умов. У статmі проаналізована структура властивостей особистості у зв'язку із професійними й особистісними якостями працівників поліції. Виявлено вплив знань, умінь, навичок на 
профілактику змін психоемоиійного фону, пов'язаних зі стресом, напругою та тривогою, характерними для виконання професійних обов'язків. Показана динаміка провісників несприятливих станів $i$ необхідність проведення профілактичних заходів з урахуванням умов служби. Проведені дослідження показали, щзо у проиесі навчання нівелюються несприятливі психічні якості особистості, пов'язані з браком знань $i$, можливо, дефектами виховання, а ие усуває умови виникнення $i$ розвитку несприятливих психічних станів, зумовлених адаптацією до вимог навчального процесу. Штатним психологам необхінно враховувати, щзо у багатьох курсантів під час встуnу на службу є основа необхіннх для професії якостей, але у процесі діяльності у них накопичуеться досвід на фоні нівелювання необхідних психологічних професійно важливих якостей. Тому проведення навчальних психологічних тренінгів під час навчання $\epsilon$ запорукою професійної adanmau̧iï.

Ключові слова: стрес, психологічний супровід, передвісники несприятливих психічних станів.

Nykyforova O., Boiko O. The optimization of the important competencies of the future officers of patrol police

The article deals with the analysis of the professionally important qualities structure as well as with their connection with the unfavorable mental states. Psychological specificity is also associated with the effects of such extreme factors as danger and extreme dynamism; lack of time and information; uncertainty about possible options of the situation change; the need to immediately solve problems that require non-standard, creative approach; high responsibility for the consequences of the decisions made. Such conflict situations have a significant psychological impact on the policeman. They create difficulties in solving professional problems, affect the success of actions, require staff's psychological stability and special training. The structure of personal qualities is analyzed, touching upon the connection of professional and personal qualities of the police officers. The influence of knowledge and skills on the prevention of changes in psycho-emotional background related to stress, tension and anxiety, which are characteristic for the performance of professional duties, are revealed. The dynamics of predictors of adverse conditions and the need for preventive measures taking into account the conditions of service are shown. Studies have shown that in the course of training, the unfavorable mental qualities of the individual, associated with the lack of knowledge and possible defects in education, are eliminated, which eliminates the conditions of origin and development of unfavorable mental states caused by the adaptation to the requirements of the educational process. Regular psychologists need to keep in mind that many cadets joining the police service have the basis of the required profession qualities, but in the course of their activity they gain background experience - leveling the necessary psychologically important qualities. Therefore, educational psychological trainings are the key to the formation of professional adaptation.

Key words: stress, psychological support, harbingers of adverse mental states.

\section{Література}

1. Велитченко Л.К. Педагогічна взаємодія: теоретичні основи психологічного аналізу : монографія. Одеса, 2005. 355 c.

2. Sparrow M. Implementing Community Policing. 38 Perspectives on Policing Washington, DC : National Institute of Justice and Harvard University, Italics, model labels and numbers added, 2008. 21,22. P. 187-194.

3. Sherwood L., Hegarty S., Valliures F., Hyland P., Murphy J., Fitzgerald G., 


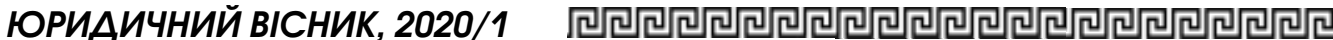

Reid T. Identifying the Key Risk Factors for Adverse Psychological Outcomes Among Police Officers: A Systematic Literature Review. J Trauma Stress. 2019. № 32 (5). P. 688-700. doi: 10.1002/jts.22431. Epub 2019 Sep 25.

4. Мельничук I.М. Цільові аспекти використання тренінгів. Психолого-педагогічні проблеми сучасної освіти. 2007. Bun. 19. C. 68-77.

5. Про подальший розвиток служби психологічного забезпечення оперативно-службової діяльності органів внутрішніх справ України : Наказ МВС України від 28 липня 2004 р. № 842.

6. Про затвердження Порядку організації системи психологічного забезпечення поліцейських, працівників Національної поліціі України та курсантів (слухачів) закладів вищої освіти із специфічними умовами навчання, які здійснюють підготовку поліцейських : Наказ МВС України від 06 лютого 2019 р. № 88.

7. Клименко Т.С. Психологическая диагностика и развитие коммуникативной компетентности сотрудников органов внутренних дел : учебное пособие. Москва 2014. С. 97

8. Караваев А.Ф., Крук В.М., Носс И.Н., Виноградов М.В. Проблемы личностно-про- фессиональной диагностики в профотборе кандидатов на службу в органах внутренних дел и оценки надежности. Психопедагогика в правоохранительных органах. 2015. № 3 (62). C. 106-113.

9. Цветков В.Л., Хрусталева Т.А. Профиль профессиональных компетенций психолога органов внутренних де. Психопедагогика в правоохранительных органах. 2015. № 2 (61). C. 22-26.

10. Graaff A.M., Cuijpers P., Acarturk C. Eur. Effectiveness of a peer-refugee delivered psychological intervention to reduce psychological distress among adult Syrian refugees in the Netherlands: study protocol. Psychotraumatol. 2020. № 11 (1). doi: 10.1080/20008198.2019.1694347.

11. Chirico F., Sharma M., Zaffina S., Magnavita $N$. Spirituality and Prayer on Teacher Stress and Burnout in an Italian Cohort: A Pilot, Before-After Controlled Study. Front Psychol. 2020. № 10. P. 29-33. doi: 10.3389 / fpsyg.2019.02933.

12. Pluntke U., Gerke S., Sridhar A., Weiss J., Michel B. Evaluation and Classification of Physical and Psychological Stress in Firefighters using Heart Rate Variability. Conf Proc IEEE Eng Med Biol Soc. 2019. Jul. P. 2207-2212. doi: 10.1109/ EMBC.2019.8856596. 